Research

\title{
Human immunodeficiency virus type I specific cytotoxic $T$ lymphocyte responses in Chinese infected with HIV-I B'/C Recombinant (CRF07_BC)
}

\author{
Jianping Chen ${ }^{\dagger 1}$, Kunxue Hong ${ }^{\dagger}$, Mingming Jia ${ }^{1}$, Hongwei Liu ${ }^{1}$, \\ Yuanzhi Zhang ${ }^{2}$, Sha Liu ${ }^{1}$, Xiaoqing Zhang1, Hongjing Zhao' ${ }^{1}$, Hong Peng1, \\ Pengfei Ma1, Hui Xing1, Yuhua Ruan1, Katie L Williams ${ }^{3}$, Xu G Yu³, \\ Marcus Altfeld ${ }^{3}$, Bruce D Walker ${ }^{3}$ and Yiming Shao*1
}

Address: ${ }^{1}$ State Key Laboratory for Infectious Disease Control and Prevention, National Center for AIDS/STD Control and Prevention, Chinese Center for Disease Control and Prevention, Beijing 100050, China, ${ }^{2}$ Xinjiang Center for Disease Control and Prevention, Urumuqi, Xinjiang 830011, China and ${ }^{3}$ Partners AIDS Research Center, Massachusetts General Hospital, and Division of AIDS, Harvard Medical School, Boston, MA 02114, USA

Email: Jianping Chen - jping_chen@chinaaids.cn; Kunxue Hong - hongkx@chinaaids.cn; Mingming Jia - jiamingming@gmail.com; Hongwei Liu - hongweiliu36@hotmail.com; Yuanzhi Zhang - yzzhang@xj.cninfo.net; Sha Liu - queenny330@yahoo.com.cn; Xiaoqing Zhang - xiaoqingzhang628@sina.com; Hongjing Zhao - zhaohongjing040@sina.com; Hong Peng - phwhs@btamail.net.cn; Pengfei Ma - mapengfei82@126.com; Hui Xing -xingh@chinaaids.cn; Yuhua Ruan - yh_ruan@sohu.com;

Katie L Williams - kwilliams20@partners.org; Xu G Yu - xyu@partners.org; Marcus Altfeld - maltfeld@partners.org;

Bruce D Walker - bwalker@partners.org; Yiming Shao* - yshao@bbn.cn

* Corresponding author †Equal contributors

Published: 30 August 2007

Retrovirology 2007, 4:62 doi:10.1 I86/1742-4690-4-62

This article is available from: http://www.retrovirology.com/content/4/I/62

(C) 2007 Chen et al; licensee BioMed Central Ltd.

This is an Open Access article distributed under the terms of the Creative Commons Attribution License (http://creativecommons.org/licenses/by/2.0), which permits unrestricted use, distribution, and reproduction in any medium, provided the original work is properly cited.
Received: 5 June 2007

Accepted: 30 August 2007

\begin{abstract}
Background: The characterization of HIV-I-specific T cell responses in people infected with locally circulating HIV-I strain will facilitate the development of HIV-I vaccine. Sixty intravenous drug users infected with HIV-I circulating recombinant form 07_BC (CRF07_BC), which has been spreading rapidly in western China from north to south, were recruited from Xinjiang, China to assess the HIV-I-specific T cell responses at single peptide level with overlapping peptides (OLP) covering the whole concensus clades $B$ and $C$ proteome.
\end{abstract}

Results: The median of the total magnitude and total number of OLPs recognized by CTL responses were $10925 \mathrm{SFC/million}$ PBMC and 25 OLPs, respectively, when tested by clade C peptides, which was significantly higher than when tested by clade B peptides. The immunodominant regions, which cover I4\% (58/4I3) of the HIV-I proteome, are widely distributed throughout the HIV-I proteome except in Tat, Vpu and Pol-PR, with Gag, Pol-RT, PolInt and Nef being most frequently targeted. The subdominant epitopes are mostly located in p24, Nef, integrase, Vpr and Vif. Of the responses directed to clade C OLPs, 6I.75\% (972/I574) can be observed when tested with corresponding clade B OLPs. However, Pol-PR and Vpu tend to be targeted in the clade $B$ sequence rather than the clade $C$ sequence, which is in line with the recombinant pattern of CRF07_BC. Stronger and broader CTL responses in subjects with CD4 cell counts ranging from 200 to $400 / \mathrm{mm}^{3}$ were observed when compared to those with less than 200/ $\mathrm{mm}^{3}$ or more than $400 / \mathrm{mm}^{3}$, though there have been no significant correlations identified between the accumulative CTL responses or overall breadth and CD4 cell count or plasma viral load. 
Conclusion: This is the first study conducted to comprehensively address $\mathrm{T}$ cell responses in Chinese subjects infected with HIV-I CRF07_BC in which subtle differences in cross-reactivity were observed, though similar patterns of overall immune responses were demonstrated with clade $B$ infected populations. The immunodominant regions identified in this population can facilitate future HIV-I vaccine development in China.

\section{Background}

HIV-1 specific cytotoxic T lymphocyte (CTL) responses play pivotal roles in driving HIV-1 evolution [1-3] and controlling viral infection [4,5]. Immune escape through mutations within CTL epitopes is rapidly accumulated in the HIV-1 genome [1-3], indicating the existence of a strong selective pressure of immune responses on HIV-1 evolution. Dramatic declines of initial peak viremia to viral set point are observed in acute HIV-1 infection with the emergence of CTL responses[4] and strong CTL responses are detected in long-term nonprogressors with chronic HIV-1 infection [5]. At the population level, the correlation between HIV-1-specific, especially Gag-specific, CTL responses and immune control have been observed and confirmed in independent cohort studies [6-8]. Therefore, prophylactic and therapeutic HIV-1-specific vaccine candidates aiming at eliciting potent HIV-1specific $\mathrm{T}$ cell responses are increasingly being tested in pre-clinical and clinical trials.

The measurement of CTL responses using peptide sets covering the whole HIV-1 expressed genome has been employed in many previous studies and covering multiple ethnicities including African, Caucasian, and Hispanic populations [9-13]. From these studies, consistent CTL targeting of immunodominant regions in the HIV-1 proteome has been recorded [10] and a high degree of interclade cross-reactivity of HIV-1-specific T cell responses at the single peptide level has been observed [14]. However, the high genetic diversity of HIV-1, which is driven by high mutation rates and inter-subtype recombination rates, is a major obstacle in the successful immune containment of viral infection and therefore the design of an HIV-1 vaccine [15]. Previous studies have mainly focused on populations infected with HIV-1 clades B and clade C, which are found circulating widely throughout the world. However, the characterization of CTL responses in people infected with locally circulating HIV-1 has yet to be thoroughly conducted.

As a developing and most populous country, China is currently facing great challenges of the HIV-1 epidemic and 650,000 people are estimated to be living with HIV/AIDS in China by the end of 2005[16]. The epidemic is mainly driven by the wide spread of clade $\mathrm{B}^{\prime}$ in former plasma donors and $\mathrm{B}^{\prime} / \mathrm{C}$ recombinant (Circulating Recombinant Form 07_BC, CRF07_BC) in intravenous drug users
(IDUs)[17]. The CRF07_BC, showing mosaic pattern in its genome with a clade $\mathrm{C}$ backbone inserted by several clade Thai B fragments in Gag, Pol, Env and accessory genes $[18,19]$ has been spreading rapidly in western China from north to south [20-22]. In this study, we assessed the profile of CTL responses in a Chinese IDU population infected with HIV-1 CRF07_BC. By employing ELISPOT using 2 sets of peptides covering the consensus clades $\mathrm{B}$ and C HIV-1 whole expressed genome, we have evaluated the breadth, magnitude, immunodominance and crossrecognition of CTL responses in this CRF07_BC infected Chinese population. The correlation between CTL responses and the containment of viral replication was also explored.

\section{Results}

Previous studies have shown that HIV-1 clade C infection may result in decreased disease progression when compared to clade $\mathrm{B}$ infection, which also correlates with the rapid outspread of clade $C$ strains in South Africa and the Indian subcontinent [23-25]. To obtain new insight on this issue, here we focused on the immunological responses of a Chinese population infected with CRF07_BC, a form of $\mathrm{B}^{\prime} / \mathrm{C}$ recombinant whose genome comprises of a clade $\mathrm{C}$ backbone and several insertions derived from Thai $\mathrm{B}[18,21,22]$.

\section{ELISPOT measured the CD8 CTL responses}

We compared the cumulative HIV-1 specific $\mathrm{T}$ cell responses, which were derived from the addition of individual positive responses in ELISPOT assays at the single peptide level and in ICS assays using peptide pools. The data indicate that the ELISPOT results are very consistent with the ICS results $(\mathrm{R}=0.96, \mathrm{p}<0.001)$. Three-color ICS was used to discriminate between the CD8 and CD4 T cell responses measured in ELISPOT and only 3 of the 60 subjects had significant CD4 T cell responses in this study.

\section{The magnitude and breadth of HIV-I specific CTL responses}

We examined the magnitude and frequency of recognition at the single peptide level in this study population (Figure 1, Table 1). Similar clustering patterns of CTL responses targeting the clades $\mathrm{B}$ and $\mathrm{C}$ proteome were observed (Figure $1 \mathrm{~A})$. However, when looking at the single peptide level, the average magnitude of CTL responses and percent of responders in the study population were significantly 
different between clades B and C peptide sets ( $p$ value of 0.009 and $<0.001$ respectively, Wilcoxon Signed Rank Test) (Figure 1B, C).

In Table 1, we have summarized the total and protein-specific magnitude and breadth of CTL responses measured in this study population for clades $\mathrm{B}$ and $\mathrm{C}$ peptides. Overall, we find that the responses targeting clade $\mathrm{C}$ proteins are stronger and broader than clade $\mathrm{B}$ proteins, with the exceptions being the Pol-PR and Vpu proteins. When tested with clade $\mathrm{B}$ peptides, the median of the total magnitude was 6,920 SFC/million PBMC with a range of 43066,290 SFC/million PBMC, which is significantly lower than when tested by clade $\mathrm{C}$ peptides (median of 10925 SFC/million PBMC with the range of 210-66,130 SFC/ million PBMC) ( $\mathrm{p}<0.001$, paired t-test). For the median of the total number of OLPs recognized, there was also a significant difference between clades $\mathrm{B}$ and $\mathrm{C}$ peptides (median of 20.0 OLPs with the range of 4-59 OLPs by clade B peptide versus 24.5 OLPs with the range of 3-63 OLPs by clade C peptide, $\mathrm{p}<0.001$, paired t-test). When responses, within specific gene products, targeting clades $\mathrm{B}$ and $\mathrm{C}$ peptides were compared, the responses targeting Gag-p17，Env-gp120，Env-gp41，Pol-RT, Pol-RNase pro- teins are significantly broader and stronger for clade $\mathrm{C}$ (Table 1). For Rev, the difference in magnitude is of no significance, while the breadth is statistically significant (clade C > B). However, we observed that for Pol-PR and Vpu proteins, the responses targeting clade $\mathrm{B}$ proteins are broader and stronger than for clade $\mathrm{C}$.

We have observed that up to $71.8 \%$ of the expressed HIV1 clade $\mathrm{C}$ proteome can be targeted in this study population, compared with only $63.7 \%$ of the expressed HIV-1 clade $\mathrm{B}$ proteome. The most frequently targeted proteins are Gag-p24, Nef and Pol-RT, to which more than $85 \%$ of the subjects mounted CTL responses. However, only less than $20 \%$ of subjects recognize at least one peptide within the Vpu and Tat proteins.

\section{Immunodominance and cross-recognition analysis}

We tried to identify the immunodominant region in the $\mathrm{B}^{\prime} / \mathrm{C}$ recombinant strains and found that there are 52 and 37 peptides from the clades $\mathrm{C}$ and $\mathrm{B}$ proteome, respectively, targeted by at least $15 \%$ of the subjects (Figure 2). These immunodominant OLPs (52 clade $\mathrm{C}$ and 37 clade B, total 89$)$ cover $14 \%(58 / 413)$ of the HIV-1 proteome. In other words, 62 of the immunodominant OLPs

Table I: Distribution of CTL Responses (breadth and strength) between HIV proteins

\begin{tabular}{|c|c|c|c|c|c|c|c|c|}
\hline \multirow[t]{2}{*}{ Protein } & \multicolumn{2}{|c|}{ No. of Peptides } & \multicolumn{2}{|c|}{$\begin{array}{l}\text { No. of OLP targeted at least } \\
\text { once in the cohort (\%) }\end{array}$} & \multicolumn{2}{|c|}{$\begin{array}{c}\text { No. of subjects with responses } \\
(\%)\end{array}$} & \multicolumn{2}{|c|}{$\begin{array}{l}\text { CTL strength (Mean } \pm \text { SD) } \\
\text { (SFC/I06 PBMC) }\end{array}$} \\
\hline & B & C & B & C & B & C & B & C \\
\hline Gag-p / 7* & 17 & 17 & I4(82.4\%) & $16(94.1 \%)$ & $32(53.3 \%)$ & $43(71.7 \%)$ & $610 \pm 1185$ & $964 \pm 1340$ \\
\hline Gag-p24 & 31 & 31 & $30(96.8 \%)$ & $30(96.8 \%)$ & $5 I(85.0 \%)$ & $52(86.7 \%)$ & $3155 \pm 3894$ & $2935 \pm 3390$ \\
\hline Gag-p/5 & 19 & 19 & $12(63.2 \%)$ & $13(68.4 \%)$ & $32(53.3 \%)$ & $34(56.7 \%)$ & $767 \pm 1495$ & $698 \pm 1290$ \\
\hline Gag & 67 & 67 & $56(83.6 \%)$ & $59(88.1 \%)$ & $55(91.7 \%)$ & $54(90.0 \%)$ & $4532 \pm 5512$ & $4597 \pm 5073$ \\
\hline Pol - Pro*\# & 21 & 21 & $12(57.1 \%)$ & $6(28.6 \%)$ & $22(36.7 \%)$ & II (I8.3\%) & $437 \pm 949$ & $240 \pm 729$ \\
\hline $\mathrm{Pol}-R T^{*}$ & 59 & 59 & $40(67.8 \%)$ & $47(79.7 \%)$ & $46(76.7 \%)$ & $53(88.3 \%)$ & $1047 \pm 1461$ & $2104 \pm 2691$ \\
\hline Pol-Rnase* & 17 & 17 & $9(52.9 \%)$ & $12(70.6 \%)$ & $14(23.3 \%)$ & $33(55.0 \%)$ & $250 \pm 1066$ & $562 \pm 1258$ \\
\hline Pol - Int & 36 & 36 & $27(75.0 \%)$ & $30(83.3 \%)$ & $38(63.3 \%)$ & $42(70.0 \%)$ & $864 \pm 1158$ & $922 \pm 1228$ \\
\hline Pol* & 133 & 133 & $88(66.2 \%)$ & $95(71.4 \%)$ & $52(86.7 \%)$ & $58(96.7 \%)$ & $2598 \pm 3069$ & $3828 \pm 4090$ \\
\hline Env-gp / 20* & 68 & 68 & $28(41.2 \%)$ & $39(57.4 \%)$ & $32(53.3 \%)$ & $38(63.3 \%)$ & $690 \pm 1445$ & $1034 \pm 2062$ \\
\hline Env-gp4I* & 46 & 46 & $17(37.0 \%)$ & $3 I(67.4 \%)$ & $29(48.3 \%)$ & $45(75.0 \%)$ & $649 \pm 1377$ & $943 \pm 1389$ \\
\hline Env* & 114 & 114 & $45(39.5 \%)$ & $70(61.4 \%)$ & $46(76.7 \%)$ & $52(86.7 \%)$ & $1339 \pm 2040$ & $1976 \pm 2624$ \\
\hline Nef & 27 & 27 & $26(96.3 \%)$ & $24(88.9 \%)$ & $52(86.7 \%)$ & $51(85.0 \%)$ & $2727 \pm 4305$ & $2812 \pm 4217$ \\
\hline Rev & 15 & 14 & $10(66.7 \%)$ & $9(64.3 \%)$ & $18(30.0 \%)$ & $28(46.7 \%)$ & $552 \pm|42|$ & $590 \pm 1105$ \\
\hline Tat & 13 & 13 & $7(53.8 \%)$ & $6(46.2 \%)$ & $10(16.7 \%)$ & $9(15.0 \%)$ & $283 \pm 1103$ & $132 \pm 496$ \\
\hline$V_{p u}^{*} \#$ & 9 & 9 & $8(88.9 \%)$ & $3(33.3 \%)$ & $9(15.0 \%)$ & $3(5.0 \%)$ & $144 \pm 535$ & $24 \pm 115$ \\
\hline Vpr & 11 & 11 & $10(90.9 \%)$ & $11(100 \%)$ & $27(45.0 \%)$ & $27(45.0 \%)$ & $532 \pm 1070$ & $522 \pm 988$ \\
\hline Vif & 24 & 24 & $13(54.2 \%)$ & $19(79.2 \%)$ & $20(33.3 \%)$ & $37(61.7 \%)$ & $576 \pm 1627$ & $762 \pm 1483$ \\
\hline Total * & 413 & 412 & $263(63.7 \%)$ & $296(71.8 \%)$ & $60(100 \%)$ & $60(100 \%)$ & $\begin{array}{l}13283 \pm \\
14223\end{array}$ & $\begin{array}{l}15242 \pm \\
14353\end{array}$ \\
\hline
\end{tabular}

$1 . *$ denotes a significant difference in responses targeting clade $B$ and C OLPs ( $p$ value $<0.05$, paired $t$ test).

2. \# denotes that the CTL responses to clade B OLPs targeting protease and $\mathrm{Vpu}$ are significantly stronger and broader than to clade $C$ OLPs 

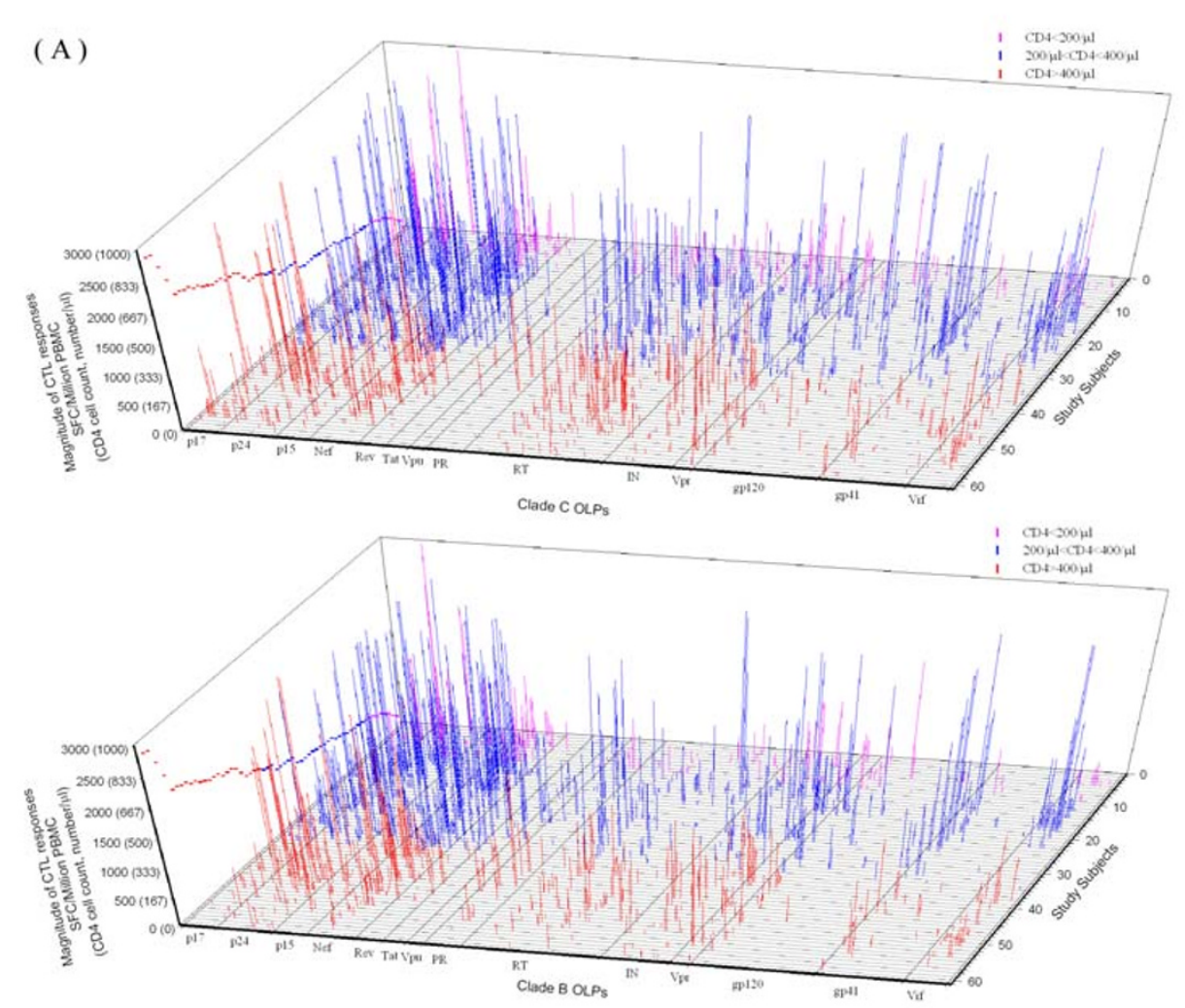

( B )

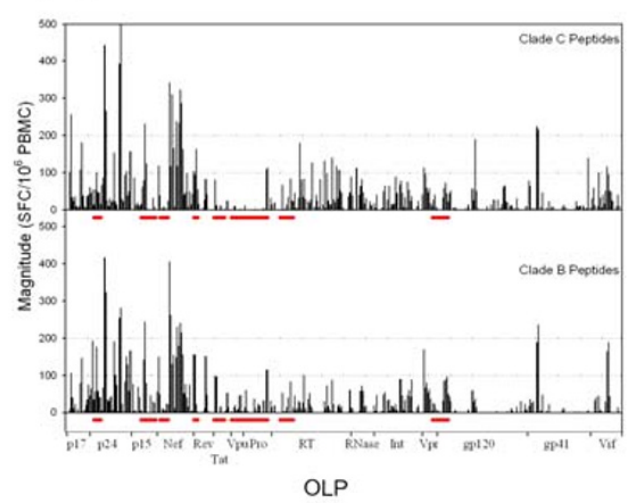

( C )

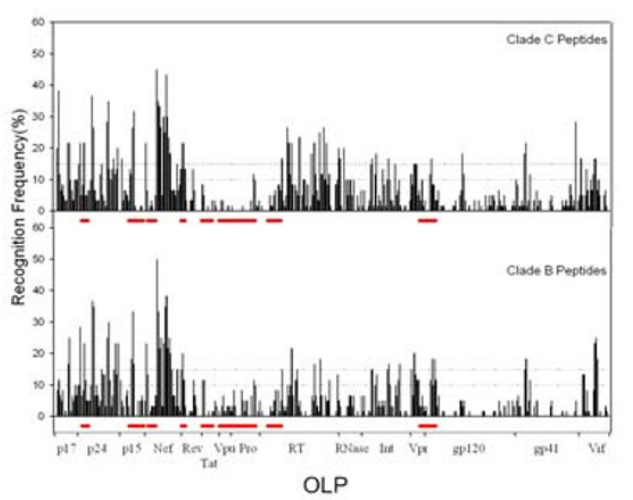

Figure I

The overall CTL responses in the study population. (A) 3-D figures depicting individual CTL responses showing similar clustering patterns targeting clade $B$ and Clade $C$ peptide sets. The CD4 counts of each subject are dotted in the left of the figures. (B) The average magnitudes induced by individual peptides covering the clades $B$ and $C$ proteome. (C) The recognition frequency of individual peptides by the study population. Inserted clade B fragments in the CRF07_BC genome are indicated as red bars adjacent to the $X$-axis. Significant differences were observed when comparing the average magnitude (B) and percent of responders $(\mathrm{C})$ for different peptide sets. 
Table 2: Sequence comparison of clade B and clade C immunodominant OLPs with different frequency of CTL Responses induced in the study population

\begin{tabular}{|c|c|c|c|c|c|c|c|c|}
\hline \multirow[t]{2}{*}{$\begin{array}{l}\text { OLP } \\
\text { Numbering }\end{array}$} & \multicolumn{3}{|c|}{ Peptide Sequences } & \multicolumn{2}{|c|}{ Percent of Responders } & \multicolumn{2}{|c|}{$\begin{array}{c}\text { Average } \\
\text { Magnitude of } \\
\text { Responders }\end{array}$} & \multirow[b]{2}{*}{ p-value } \\
\hline & Clade B & Clade C & Location & Clade B & Clade C & Clade B & Clade C & \\
\hline GAG-46 & 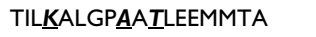 & TILRALGP白A $\underline{\boldsymbol{R}}$ LEEMMTA & Gag (332 - 349) & $23.33 \%$ & $11.67 \%$ & 553 & 334 & 0.022 \\
\hline POL-I26 & $\underline{T}$ KIQNFRVYYRDSRDPLW & IKIQNFRVYYRDSRDPIW & Pol $(933-950)$ & $16.67 \%$ & $10.00 \%$ & 535 & 358 & 0.027 \\
\hline VPR-4 & ELK $\underline{R} E A V R H F P R P W L H G L$ & ELKQEAVRHFPRPWLHGL & $\operatorname{Vpr}(25-42)$ & $20.00 \%$ & $15.00 \%$ & 405 & 400 & 0.039 \\
\hline ENV-8 & LFCASDAKAYDTEVHNVW & LFCASDAKAYEKEVHNVW & gpl60 (52-69) & $18.33 \%$ & $8.33 \%$ & 525 & 540 & N.S. \\
\hline VIF-I5 & 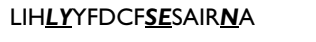 & 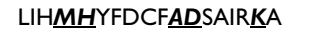 & $\operatorname{Vif}(106-123)$ & $18.33 \%$ & $6.67 \%$ & 241 & 773 & N.S. \\
\hline GAG-03 & 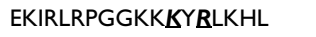 & EKIRLRPGGKK $\underline{H} Y \underline{M L K H L}$ & Gag $(17-34)$ & $8.33 \%$ & $20.00 \%$ & 128 & 517 & 0.039 \\
\hline GAG-04 & GKKKKYㅁLKHLVWASREL & GKK $\underline{H Y} \underline{M} L K H L V W A S R E L$ & Gag $(25-4 I)$ & $11.67 \%$ & $38.33 \%$ & 911 & 670 & 0.023 \\
\hline GAG-5I & TNSATIMMQRGNFRNQRK & NSAILMQRSNFKGSKR & Gag (37I - 388) & $5.00 \%$ & $16.67 \%$ & 87 & 520 & 0.016 \\
\hline REV-03 & RIVRLIKLLLQSNP $\underline{L}$ & RㅁRIIKILYQSNPY & $\operatorname{Rev}(14-28)$ & $11.67 \%$ & $21.67 \%$ & 197 & 754 & 0.013 \\
\hline POL-43 & QGWKGSPAIFQCSMTKIL & QGWKGSPAIFQ & Pol $(306-323)$ & $10.00 \%$ & $26.67 \%$ & 268 & 672 & 0.000 \\
\hline POL-44 & IFQCSMTKILEPFR $\underline{K}$ & IFQSSSMTKILEPFR $\underline{A}$ & Pol $(3 \mid 4-328)$ & $6.67 \%$ & $21.67 \%$ & 163 & 371 & 0.010 \\
\hline POL-6I & TKALTEVVPLTEEAELEL & $\underline{A K A L T} \underline{\text { DIVPLTEEAELEL }}$ & Pol $(44 I-458)$ & $6.67 \%$ & $18.33 \%$ & 460 & 723 & 0.020 \\
\hline POL-70 & MRGAHTNDVKQLTEAVQK & MRTAHTNDVKQLTEAVQK & Pol $(5 \mid 2-529)$ & $0.00 \%$ & $26.67 \%$ & 0 & 441 & 0.002 \\
\hline POL-72 & QKIA $\underline{T E S I V I W G K T P K F \underline{K}}$ & QKIAMESIVIWGKTPKF $\underline{R}$ & Pol $(528-545)$ & $5.00 \%$ & $21.67 \%$ & 420 & 495 & 0.008 \\
\hline POL-8I & DGAANRETKLGGAGYV & DGAANRETKIGKAGYV & Pol $(598-613)$ & $5.00 \%$ & $20.00 \%$ & 253 & 448 & 0.012 \\
\hline POL-82 & ETKLGKAGYVT $\underline{N K G R Q K \underline{V}}$ & ETKIGKAGYVTDRGRQK $\underline{I}$ & Pol $(604-62 I)$ & $3.33 \%$ & $16.67 \%$ & 350 & 236 & 0.078 \\
\hline POL-85 & QKTELQAI $\underline{H L A L Q D S G} \underline{\underline{L}}$ & QKTELQAIYLALQDSG $\underline{\boldsymbol{S}}$ & Pol $(630-646)$ & $0.00 \%$ & $20.00 \%$ & 0 & 563 & 0.001 \\
\hline POL-109 & PAETGQETAYFLLLKLAGR & PAETGQETAYFILKLLAGR & Pol $(805$ - 822) & $13.33 \%$ & $18.33 \%$ & 264 & 352 & N.S. \\
\hline ENV-29 & KVㅁFEPIPIHYCAPAGFA & KVIFDPIPIHYCAPAGYA & gpl $60(207-224)$ & $3.33 \%$ & $18.33 \%$ & 1120 & 1040 & 0.015 \\
\hline ENV-II3 & $\underline{Y}$ RAILHIPIRIRQGLEERA & $\underline{C} R A|\underline{R} N| P \underline{R} R I R Q G \underline{F} E \underline{A} A$ & gpl $60(837-854)$ & $5.00 \%$ & $28.33 \%$ & 110 & 489 & 0.000 \\
\hline VIF-3 & 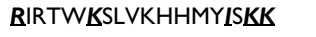 & $\underline{K I R T W} \underline{N} S L V K H H M Y \underline{V} \underline{R R}$ & Vif $(17-34)$ & $0.00 \%$ & $16.67 \%$ & 0 & 354 & 0.007 \\
\hline
\end{tabular}

$P$ values were for comparison of paired t-test and $p=0.05$ is considered as statistic significance level.

The peptide location were indicated in the table in the reference of HIV-I strain Hxb2.

detected are the corresponding clades B and C OLPs. Table 2 shows the pairs of immunodominant OLPs with different percentages of responders targeting clade $\mathrm{B}$ or $\mathrm{C}$ peptides. Notably, $26.7 \%$ of the subjects recognized the clade C OLP designated as Pol-70(located in RT protein), however with only one amino acid substitution (G359T) it is no longer detectable in the study subjects. It is also notable that there are 10 and 3 dominant epitopes identified in RT and RNase respectively when tested by clade C peptides, while only 3 and 0 identified by clade $B$ peptides. There are no immunodominant epitopes found in Pol-PR, Tat and Vpu. The immunodominant regions are widely distributed throughout the entire genome, with Gag, Pol and Nef being the most frequently targeted. Compared to the dominant epitopes scattered within the Gag protein, those in Nef are clustered in the central region of the protein. The subdominant epitopes, targeted by more than $10 \%$ but less than $15 \%$ of the subjects, are mostly located in p24, Nef, integrase, Vpr and Vif.

High cross-recognition of HIV-1 specific CTL responses was observed in this study. When looking at the CTL recognition frequency at the single peptide level, along with the distribution of immunodominant OLPs, the profile of cross-recognition between clade $\mathrm{B}$ and $\mathrm{C}$ peptides can clearly be seen (Figure 2). To further assess the cross-recognition of CTL responses to clades $\mathrm{B}$ and $\mathrm{C}$ peptides, the two peptide sets were classified into the following categories, (i) both $\mathrm{B}$ and $\mathrm{C}$ peptides not recognized, (ii) both $\mathrm{B}$ and $\mathrm{C}$ peptides recognized by at least one subject, (iii) only $\mathrm{C}$ peptides recognized by at least one subject and (iv) only $\mathrm{B}$ peptides recognized by at least one subject. The results are represented with a Venn diagram (Figure 3) and about $22 \%$ of the corresponding OLPs (92/413) derived from both the clades $\mathrm{B}$ and $\mathrm{C}$ proteome are not targeted by CTL. Of the remaining OLPs, more than $68 \%$ (219/ $321)$ can be cross-recognized. We also analyzed the crossrecognition by looking at the total CTL responses detected by clades $\mathrm{B}$ and $\mathrm{C}$ peptide sets. There are 1352 responses observed when applying clade B OLPs, and 1574 responses to clade $\mathrm{C}$ OLPs. Of the responses directed to clade C OLPs, 61.75\% (972/1574) can be observed when tested with corresponding clade B OLPs.

\section{Correlation of CTL responses with immune control of HIV- I infection}

Firstly, we examined the correlation of CTL responses with CD4 cell counts and viral loads and found that there are no significant correlations between the overall breadth of responses and the CD4 cell count or plasma viral load. However, a weak negative correlation between the total magnitude and the CD4 cell count was observed $(\mathrm{R}=$ $0.260, \mathrm{p}=0.0442$ for clade $\mathrm{B}$ OLP set; $\mathrm{R}=-0.283, \mathrm{p}=$ 0.0285 for clade C OLP set, Pearson Correlation test). 


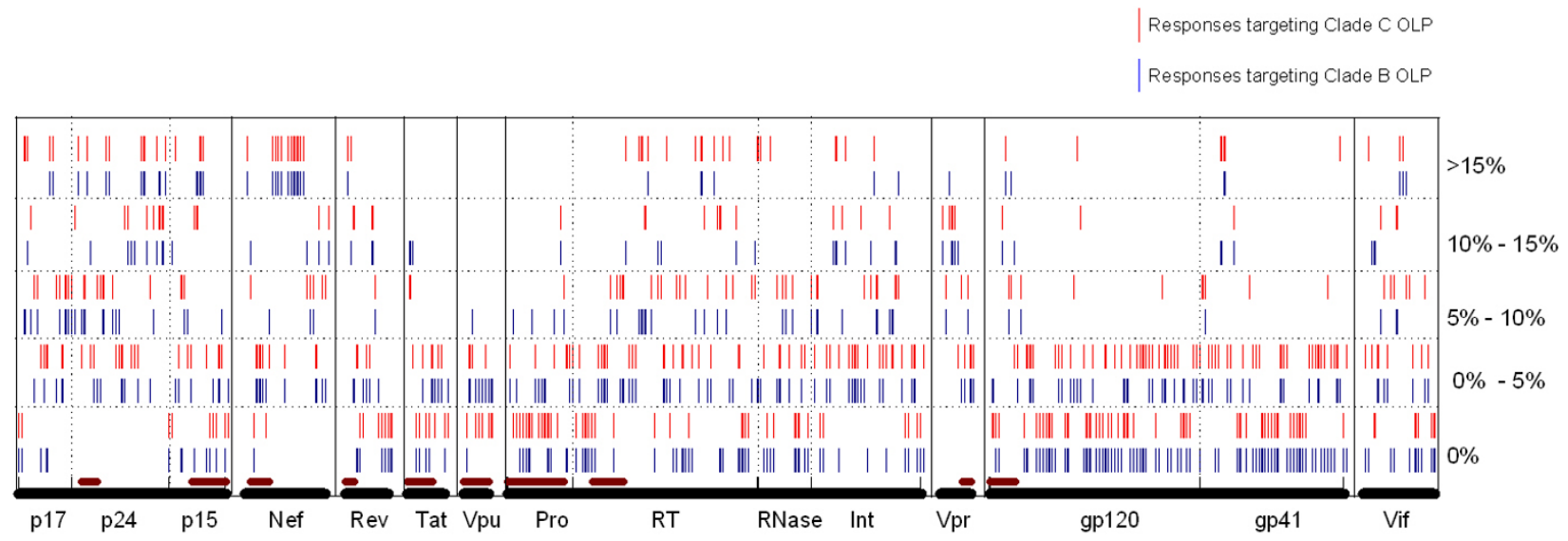

\section{Figure 2}

The immunodominance and cross-reactivity analysis. The location of immunodominant and subdominant epitopes in the HIV-I proteome. Five classes of recognition frequency are represented in the figure, (i) recognition frequency more than I5\%, (ii) more than $10 \%$ but less than $15 \%$, (iii) more than $5 \%$ but less than $10 \%$, (iv) more than $0 \%$ but less than $5 \%$ and (v) not recognized in the study population. Inserted clade B fragments in the CRF07_BC genome are indicated as red bars adjacent to X-axis.

When looking at specific HIV-1 proteins, we found that an increased breadth of CTL responses targeting Gag (especially p24 and p15) resulted in decreased plasma viral load, while for Nef and $\mathrm{Vpu}$, increased breadth or magnitude of CTL responses corresponded to increased plasma viral load. However, these correlates between the breadth of CTL responses to specific proteins and the plasma viral load can only be observed in consensus clade $C$ peptide sets, with the exception of p15. We then classified the subjects into three groups based on their CD4 cell counts and compared the breadth and magnitude of CTL responses. The results show stronger and broader CTL responses in subjects with CD 4 cell counts ranging $200-400 / \mathrm{mm}^{3}$ than those with less than $200 / \mathrm{mm}^{3}$ or more than $400 / \mathrm{mm}^{3}$. By One Way Analysis of Variance (ANOVA), we find that there are significant differences between the three groups in CTL responses targeting clade $\mathrm{B}$ Gag (magnitude $\mathrm{p}=$ 0.046 , breadth $\mathrm{p}=0.006$ ), clade $\mathrm{B} \mathrm{p} 17$ (magnitude $\mathrm{p}=$ 0.020 , breadth $\mathrm{p}=0.027$ ), and clade B p24 (breadth $\mathrm{p}=$ $0.022)$; clade $\mathrm{C}$ total breadth $(\mathrm{p}=0.032)$, clade $\mathrm{C}$ gag (breadth $\mathrm{p}=0.022$ ), clade $\mathrm{C}$ gag-p24 (breadth $\mathrm{p}=0.009$ ), clade $C$ Nef (breadth $p=0.045$, magnitude $p=0.023$ ), and clade $\mathrm{C}$ gp41 (magnitude $\mathrm{p}=0.024$ ). However, by pair wise multiple comparison, the differences with statistical significance are only observed in the breadth of clade B gag (200-400 vs. >400, unadjusted p $=0.00285 ;<200$ vs. 200-400, unadjusted $\mathrm{p}=0.0226)$, clade $\mathrm{B}$ gag-p17 (200-400 vs. $>400, \mathrm{p}<0.05)$, clade B gag-p24 (200-400 vs. $>400, \mathrm{p}<0.05)$, clade C gag-p24 (200-400 vs. >400, unadjusted $\mathrm{p}=0.00573 ;<200$ vs. $200-400$, unadjusted $\mathrm{p}$ $=0.0222)$, clade C Nef $(200-400$ vs. $>400, \mathrm{p}<0.05)$, and in magnitude of clade B Gag-p17 (200-400 vs. >400, p < $0.05)$, Clade C Nef (200-400 vs. >400, p < 0.05). Figure 4 shows the different magnitudes and breadths of CTL responses targeting Gag protein when the subjects were classified using their CD4 cell counts.

\section{Discussion}

Several studies have been performed to characterize the immune responses of HIV-1 infected populations of Chinese origin [26-29]. However, these studies have focused on subjects infected with the clade B virus, which circulates throughout central China in former plasma donors. As shown in the two nationwide HIV-1 molecular epidemiological surveys performed in China in 1998 and 2004, the $\mathrm{B}^{\prime} / \mathrm{C}$ recombinant strains (particularly CRF07_BC) are circulating in western China from south to north [18-22]. This is the first study to address the profile of cellular immune responses in Chinese subjects infected with HIV1 CRF07_BC.

It was reported that Gag, Pol and Nef are among the most frequently targeted proteins by CTL in subjects infected with HIV-1, including clades B and C $[9,10,12,13,29,30]$. Such clustering pattern of CTL epitopes in HIV-1 proteins has led to the postulate that the frequency of CTL recognition is inversely correlated with the variability of the viral sequences[31,32]. We have seen the similar clustering pattern of CTL responses targeting HIV-1 proteins in this study population infected with HIV-1 CRF07_BC. Namely, Gag, Pol and Nef are among the most frequently targeted proteins, while $\mathrm{Vpu}$ and Tat are rarely targeted 


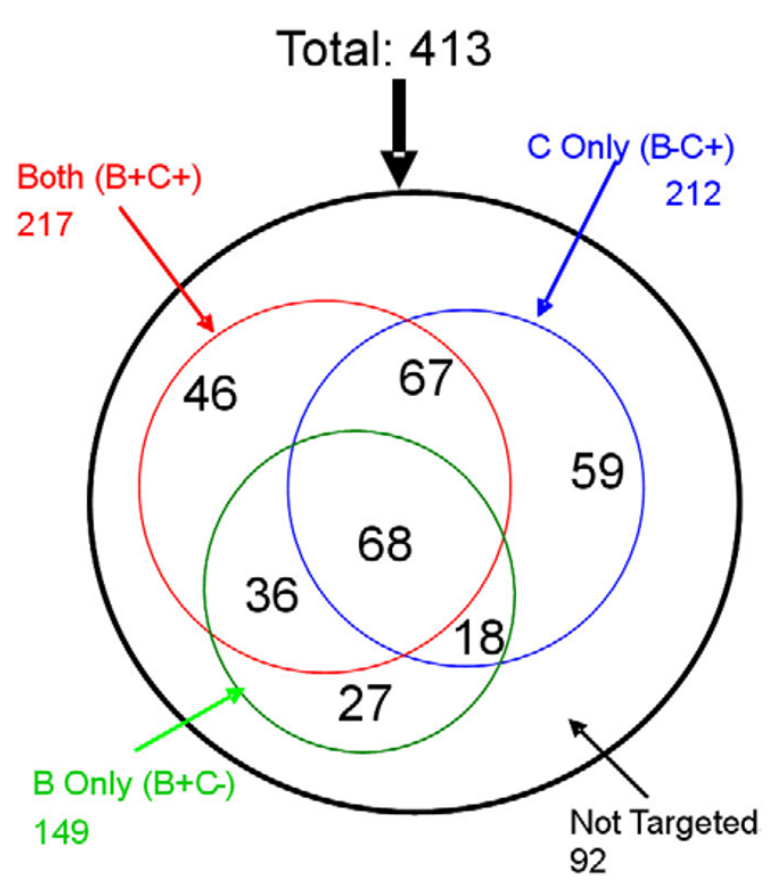

Figure 3

Area-proportional Venn diagram of cross recognition. The expressed whole genome of HIV-I clade B or clade $C$ were digested as 413 overlapping peptides and the two sets of peptides were tested in ELISPOT assay for each subject enrolled in this study. Cross-recognition of CTL responses to clade $B$ and Clade $C$ peptides were assessed by the classification of (i) both $B$ and $C$ peptides not recognized, (ii) both $B$ and $C$ peptides recognized by at least one subject, (iii) only $C$ peptides recognized by at least one subject and (iv) only $B$ peptides recognized by at least one subject.

(Figure 1, Table 1). Also, we have observed that Vpr and Vif are targeted intensively. However, Pol-PR may be exceptional to the postulate of inverse correlation between frequency of CTL recognition and variability of the viral sequences, as we have not observed immunodominant epitopes in this relatively conserved protein (Table 1, Figure 2).

The identification of immunodominant regions is crucial for vaccine development and evaluation as these are the targeted HIV regions that will be included in promising vaccines [15]. Immune escape from immunodominant epitopes can result in a broader spectrum of CTL responses and in a faster development to AIDS[1,33] and the host's genetic background may drive the elimination of subdominant yet effective epitopes from circulating viral population[34]. In this study, we identified 89 immunodominant OLPs scattering the HIV-1 proteins except for Pol-PR, Tat and Vpu (Figure 2). We also observed that the subdominant epitopes were also distrib- uted throughout the HIV-1 expressed genome. When comparing the patterns of dominant and subdominant epitopes detected by clades B or C peptides, Pol and Vif are notable for their discrepancies. The factors contributing such differentially targeting of clades B and C OLPs by CTL responses could be the cumulative effect of immune escapes during the HIV-1 epidemic in this population or the founder effects of viral linage[35]. Anyway, our data suggest that when incorporated into a vaccine construct, Gag and Nef can more easily induce cross-clade CTL responses, while the CTL responses induced by Pol and Vif are more clade-specific.

High cross-clade CTL responses have previously been extensively explored, especially in populations infected with clade B[14,29,36]. Cross-clade CD8 T-cell responses to HIV-1 CRF07_BC circulating in China have been recorded in a previous study by using recombinant vaccinia viruses containing HIV-1 genes as stimulus antigen [37]. However, by studying cross-clade CTL responses on the single peptide level, new insight can be achieved, keeping in mind that the homologous peptides can detect CTL responses better than recombinant vaccinia viruses expressed antigen and heterogeneous peptides [38]. We have demonstrated here that for the $\mathrm{B}^{\prime} / \mathrm{C}$ recombinant HIV-1 infected subjects, high cross recognition of consensus clades $\mathrm{B}$ and $\mathrm{C}$ peptides is also evident. However, we noticed that the $\mathrm{B}^{\prime} / \mathrm{C}$ recombinant strains contained part of the clade B sequences in Gag, Pol, Env, Nef and accessory genes except for Vif $[18,21]$. The relatively stronger and broader responses directed to clade $C$ peptides compared with clade $\mathrm{B}$ was consistent with the reports in other studies, which show that homologous peptides are better at detecting CTL responses [38] and different from the observation in another study on a Chinese population infected with HIV-1 Thai B [29]. In the study by Zhao S et al, they observed no significant differences between the CTL responses targeting clade B and C peptide sets[29]. This may indicate that the recombinant form of HIV-1 CRF07_BC displays subtle differences in inducing the host's immune responses. From the recognition patterns in the clades $\mathrm{B}$ and $\mathrm{C}$ proteome, we can find that Pol-PR and $\mathrm{Vpu}$ tend to be targeted in the clade $\mathrm{B}$ sequence rather than the clade $\mathrm{C}$ sequence. These data are in line with the recombinant pattern of CRF07_BC, the genome of which are inserted with fragments of clade B sequences in pol-pr and $v p u[18,21,22]$.

In the past decade, the correlation between CTL responses and immune control of HIV-1 infection has been extensively explored and controversial results have been reported[5,8,13,28,39-42]. A recent study has demonstrated that CTL responses to different HIV proteins have discordant associations with plasma viral load, which results in effective CTL responses without a demonstrable 

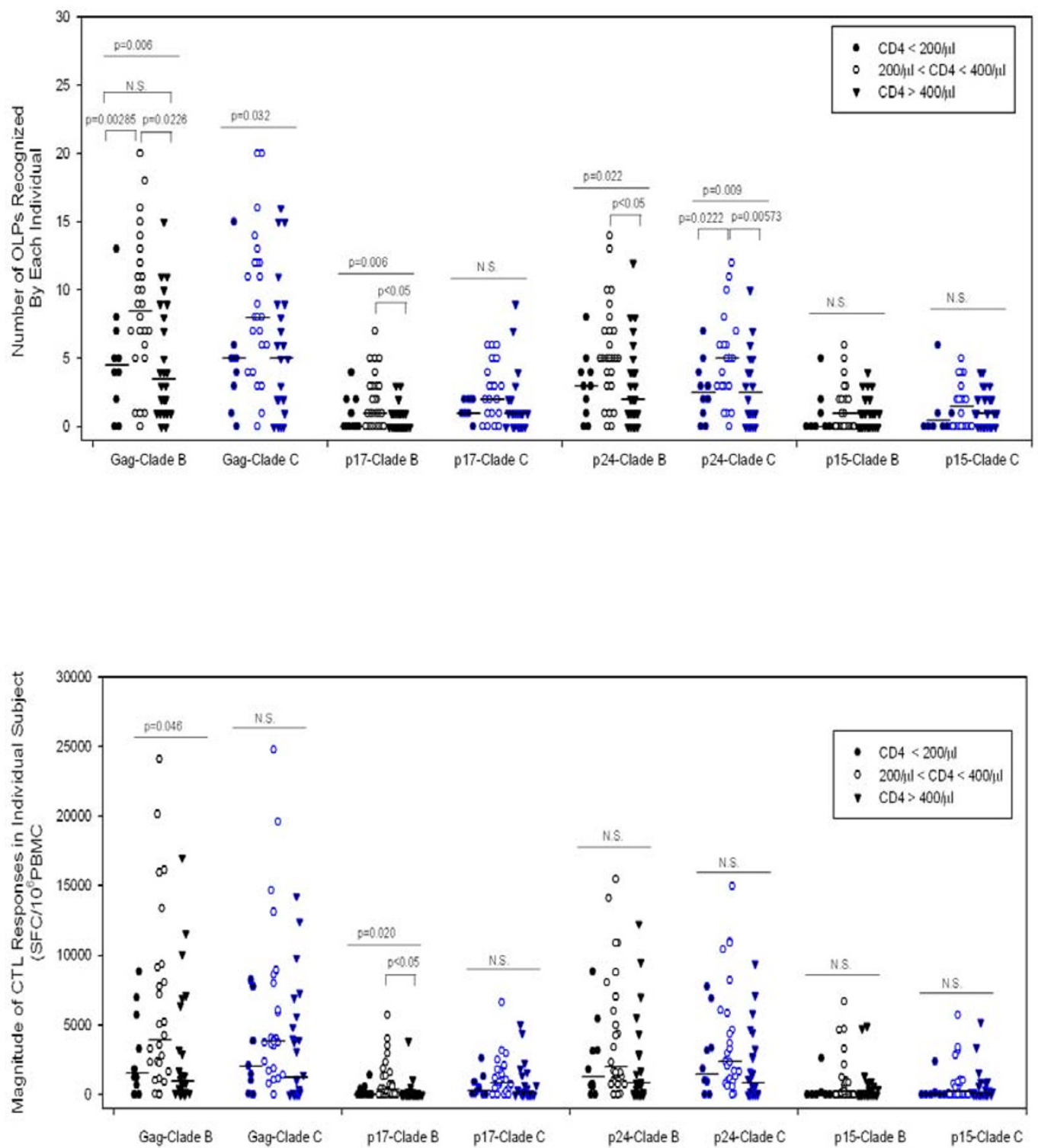

\section{Figure 4}

Subjects grouped with different CD4 cell counts mounted a different magnitude and breadth of CTL responses targeting Gag. For each portion of the HIV-I proteins (Gag, pl7, p24 or pl5), the total magnitude or breadth of each individual is dotted and the median values are shown as a dash. Black dots are responses targeting consensus clade B peptides and blue dots for responses targeting clade $C$ peptides. The filled dots designate the values from the group of CD4 cell counts less

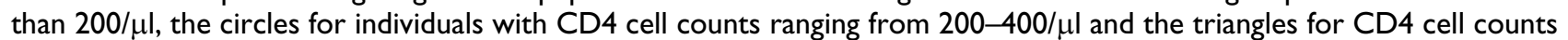
more than 400/ $\mu \mathrm{l}$. The $p$ values were obtained using One Way Analysis of Variance (ANOVA) for multiple group comparison and Dunn's method or Holm-Sidak method for pair wise multiple comparison, when appropriate for data distribution. 
biological impact in chronic HIV infection[7]. The association between the breadth of Gag-specific CTL responses and low viremia has been confirmed in several population based studies [6-8]. Consistent with these studies $[7,8]$, we have observed no statistically significant correlation between total magnitude or breadth of CTL responses and plasma viral load or CD4 cell count in this study. But the data demonstrate that the relatively broader CTL responses targeting Gag (especially Gag-p24 and p15) correlate with lower plasma viral loads, and broader CTL responses targeting Nef and Vpu correlate with increased viral loads. The rationale behind this finding is still to be elucidated. However, there are two possibilities to explain the discordance. The first possibility is that Nef and Vpuspecific CD8+ T-cell responses are as effective as Gag-specific responses in controlling viral replication, but the CTL responses are recruited sequentially to different viral antigens and escaped by virus with mutations in CTL epitopes $[1,43]$. An alternative explanation is that Nef and Vpu-specific CTL responses are inherently less effective than Gagspecific responses, partly due to the deleterious effect of the viral mutation in CTL targeted Gag protein[44]. In line with this, while several vaccine approaches that focus primarily or exclusively upon generation of a CTL responses protected macaques from disease, previous evidence also suggests that CTL-based vaccines no matter raised against densely conserved coding regions of HIV-1 spaning open reading frames such as Env, Tat and Rev simultaneously, can apparently always create viral escapes which are not necessarily confer a fitness cost[45]. Put these together, final validation of vaccine concept of eliciting protective CTL responses against invading HIV-1 will have to be obtained from large-scale efficacy clinical trial with promising HIV vaccines containing different viral products. The fact that the correlates can only be observed when tested with consensus clade $C$ peptides other than clade B peptides indicates that the choice of test peptide may have an impact on the demonstration of the correlation between the CTL responses and the containment of viral load.

The further analysis by grouping the research subjects on basis of CD4 cell count, show that subjects with CD4 cell ranging $200-400 / \mathrm{mm}^{3}$ mounted stronger CTL responses than those with less than $200 / \mathrm{mm}^{3}$ or more than 400 / $\mathrm{mm}^{3}$. The results suggest that the correlation between HIV-specific CTL responses and viral load in HIV-1 infection is dependent on disease status, which have been recorded in previous reports that weaker anti-HIV CD8+ T-cell effector activity were observed in HIV primary infection compared with asymptomatic subjects with chronic infection $[28,46]$. The decline of the HIV-1 specific CTL responses late in disease progession is also obvious and can be explained by the progressive depletion of CD4 helper T cells, which result in the inability of the body to mount broader and stronger CD8 CTL response targeting viral proteins [47], or by selective depletion of virus specific CTL [48] and the impaired proliferative capability of virus specific CD8 CTL[49], which lead to decreased effector activity of previously induced CTL responses.

\section{Conclusion}

Overall, this is the first study addressing the profile of immune responses in Chinese subjects infected with HIV$1 \mathrm{~B}^{\prime} / \mathrm{C}$ recombinants. We have found similar CTL response patterns as previous reports $[9,10,12,13,29]$. However, by comparing CTL responses targeting the clades B and C proteome in the same population, we find significant differences in the total magnitude and breadth conferred by Gag-p17, Pol, and Env. This indicates that the rapidly overspread CRF07_BC may have subtle differences in inducing a host's immune responses when compared with the HIV-1 Thai B viral strain circulating in central China.

\section{Methods}

\section{Study population}

Sixty IDUs infected with HIV-1 CRF07_BC were recruited from Urumuqi at Xinjiang Uyghur Autonomous Region, which is located in northwestern China. The clinical and demographic characteristics of these subjects were as follows: median age, 32 years (range, 23-47 years); median HIV-1 RNA, 21,550 copies/ml plasma (range, 49650,000 copies/ml plasma); median CD4 cell count, 339 cells/mm3 (range, 16-940 cells/mm3). All individuals were anti-retroviral therapy naive at the time of study and infected with HIV-1 CRF07_BC. The study was approved by the institutional review board of National Center for AIDS/STD Control and Prevention (NCAIDS, ChinaCDC) and was conducted in accordance with human experimentation guidelines.

\section{Synthetic HIV-I-peptides}

Four-hundred and thirteen synthetic 15-20 amino acid long peptides, overlapping by 10 amino acids and spanning the entire HIV-1 clade $\mathrm{B}$ or $\mathrm{C}$ consensus sequence [50], were synthesized at the Massachusetts General Hospital (MGH) Peptide Core Facility on an automated peptide synthesizer using Fmoc technology. All peptides were synthesized at the same time and using the same reagents. Except for a few cases of insertion or residue deletions between clades, corresponding peptides from the different consensus sequences were always of the same length and spanned identical regions.

\section{Elispot assays}

Elispot assays were carried out as described previously [30]. Briefly, peripheral blood mononuclear cells (PBMC) isolated by Ficoll-paque ${ }^{\mathrm{TM}}$ Plus (Amersham Biosciences) density gradient centrifugation were plated in 96-well polyvinylidene plates that had been precoated with $100 \mu \mathrm{l}$ of 
anti-human interferon-gamma monoclonal antibody (0.5 $\mu \mathrm{g} / \mathrm{ml}$, Mabtech, Stockholm, Sweden). PBMCs were plated at a concentration of 100000 cells/well in a volume of $100 \mu \mathrm{l}$ of RPMI 1640 medium supplemented with fetal calf serum (10\%), Hepes buffer (10 mM), L-glutamine (2 $\mathrm{mM})$ and penicillin-streptomycin $(50 \mathrm{U} / \mathrm{ml})$. Corresponding clades $\mathrm{B}$ and $\mathrm{C}$ peptides were combined into pools of four to six peptides and tested individually when a peptide pool gave a positive response. The final concentration of the peptides in each well was $10 \mu \mathrm{g} / \mathrm{ml}$. Plates were incubated overnight at $37^{\circ} \mathrm{C}, 5 \% \mathrm{CO}_{2}$ and developed the next day as described elsewhere [30]. Wells containing PBMC and medium with PMA/Ionomycin or without any peptide were used as positive or negative controls, respectively, and run in triplicate on each plate. To calculate the number of specific $\mathrm{T}$ cell responses, the number of spots in the negative control wells was subtracted from the counted number of spots in each well. Responses were considered positive if there were $>50$ spot-forming cells (SFC) $/ 1 \times 10^{6} \mathrm{PBMC}$ after subtracting background and at least three times the mean number of SFC of the three control wells.

\section{Intracellular Cytokine Assay}

ICS for IFN-gamma was performed as previously described [51]. $1 \times 10^{6} \mathrm{PBMC}$ were incubated with peptide pools of $2 \mu \mathrm{g} / \mathrm{ml}$ Env, Gag, Pol, Nef and VVVRT(Vif, Vpr, Vpu, Rev and Tat) along with anti-CD28 and anti-CD49 antibodies (BD Pharmingen) at $37^{\circ} \mathrm{C}$ and $5 \% \mathrm{CO}_{2}$ for 1 hour before the addition of brefeldin A $(10 \mu \mathrm{g} / \mathrm{ml}$; Sigma). The cells were incubated for an additional 5 hours at $37^{\circ} \mathrm{C}$ and $5 \% \mathrm{CO}_{2}$ and then washed and stained with anti-CD4-PE and anti-CD8-APC antibodies (BD Pharmingen) at $4{ }^{\circ} \mathrm{C}$ for $30 \mathrm{~min}$. The cells were fixed with solution A (Caltag), permeabilized with solution B (Caltag), and then stained with fluorescein isothiocyanate-conjugated anti-IFN-gamma antibody. Flow cytometric analysis was performed on FACSCalibur with CellQuest Pro (Becton Dickinson). The FCS data were analyzed with FlowJo software.

\section{Statistical analysis}

Results are given as means +/- SD or medians with ranges. Statistical analysis was performed with SigmaPlot version 10.0 (Systat Software, Inc.) and based on Student t tests, a Wilcoxon rank sum test, or a multiparametric ANOVA test, as appropriate; a $\mathrm{P}<0.05$ was considered significant. Viral-load values below the limit of detection of 50 RNA copies/ $\mathrm{ml}$ were assigned a value of 49 for statistical analyses.

\section{Competing interests}

The author(s) declare that they have no competing interests.

\section{Authors' contributions}

$\mathrm{YZ}$, YR recruited the subjects and collected the samples. JC, KH, XZ, HZ carried out the ELISPOT assays, HL, MJ, SL carrried out the ICS assays, HP, PM, HX performed the CD4 cell count and viral load tests. JC and KH carried out the data analysis and drafted the manuscript. XGY, MA, participated in the design of the study and coordination. KLW participated in the data analysis and helped to draft the manuscript. BDW, YS conceived of the study, and participated in its design and coordination. All authors read and approved the final manuscript.

\section{Acknowledgements}

This project has been funded in part with Federal fund from the National Institute of Allergy, and Infectious Disease, National Institutes of Health, under Contract NOI-AI-30024, and with International Cooperation in Science and Technology from Chinese Ministry of Science and Technology, under project 2006DFA3 I5 I0. We thank Dr Isaac R. Rodriguez-Chavez from Division of AIDS, NIAID, NIH for his proof reading the manuscript.

\section{References}

I. Feeney ME, Tang Y, Roosevelt KA, Leslie AJ, McIntosh K, Karthas N, Walker BD, Goulder PJ: Immune escape precedes breakthrough human immunodeficiency virus type I viremia and broadening of the cytotoxic T-lymphocyte response in an HLA-B27-positive long-term-nonprogressing child. J Virol 2004, 78(16):8927-8930.

2. Borrow P, Lewicki H, Wei X, Horwitz MS, Peffer N, Meyers H, Nelson JA, Gairin JE, Hahn BH, Oldstone MB, Shaw GM: Antiviral pressure exerted by HIV-I-specific cytotoxic $T$ lymphocytes (CTLs) during primary infection demonstrated by rapid selection of CTL escape virus. Nat Med 1997, 3(2):205-2II.

3. Moore CB, John M, James IR, Christiansen FT, Witt CS, Mallal SA: Evidence of HIV-I adaptation to HLA-restricted immune responses at a population level. Science 2002, 296(5572): 1439-1443.

4. Koup RA, Safrit JT, Cao Y, Andrews CA, McLeod G, Borkowsky W, Farthing C, Ho DD: Temporal association of cellular immune responses with the initial control of viremia in primary human immunodeficiency virus type I syndrome. J Virol I994, 68(7):4650-4655

5. Betts MR, Nason MC, West SM, De Rosa SC, Migueles SA, Abraham J, Lederman MM, Benito JM, Goepfert PA, Connors M, Roederer M, Koup RA: HIV nonprogressors preferentially maintain highly functional HIV-specific CD8+ T cells. Blood 2006, 107( I 2):478I-4789.

6. Geldmacher C, Currier JR, Herrmann E, Haule A, Kuta E, McCutchan F, Njovu L, Geis S, Hoffmann O, Maboko L, Williamson C, Birx D, Meyerhans A, Cox J, Hoelscher M: CD8 T-cell recognition of multiple epitopes within specific Gag regions is associated with maintenance of a low steady-state viremia in human immunodeficiency virus type I-seropositive patients. J Virol 2007, 8 I (5):2440-2448.

7. Kiepiela P, Ngumbela K, Thobakgale C, Ramduth D, Honeyborne I, Moodley E, Reddy S, de Pierres C, Mncube Z, Mkhwanazi N, Bishop K, van der Stok M, Nair K, Khan N, Crawford H, Payne R, Leslie A, Prado J, Prendergast A, Frater J, McCarthy N, Brander C, Learn GH, Nickle D, Rousseau C, Coovadia H, Mullins Jl, Heckerman D, Walker BD, Goulder P: CD8+ T-cell responses to different HIV proteins have discordant associations with viral load. Nat Med 2007, 13(I):46-53.

8. Zuniga R, Lucchetti A, Galvan P, Sanchez S, Sanchez C, Hernandez A, Sanchez H, Frahm N, Linde CH, Hewitt HS, Hildebrand W, Altfeld M, Allen TM, Walker BD, Korber BT, Leitner T, Sanchez J, Brander C: Relative dominance of Gag p24-specific cytotoxic T lymphocytes is associated with human immunodeficiency virus control. J Virol 2006, 80(6):3 I22-3I 25.

9. Addo MM, Yu XG, Rathod A, Cohen D, Eldridge RL, Strick D, Johnston MN, Corcoran C, Wurcel AG, Fitzpatrick CA, Feeney ME, Rod- 
riguez WR, Basgoz N, Draenert R, Stone DR, Brander C, Goulder PJ, Rosenberg ES, Altfeld M, Walker BD: Comprehensive epitope analysis of human immunodeficiency virus type I (HIV-I)specific $T$-cell responses directed against the entire expressed HIV-I genome demonstrate broadly directed responses, but no correlation to viral load. J Virol 2003, 77(3):208I-2092.

10. Frahm N, Korber BT, Adams CM, Szinger J], Draenert R, Addo MM, Feeney ME, Yusim K, Sango K, Brown NV, SenGupta D, PiechockaTrocha A, Simonis T, Marincola FM, Wurcel AG, Stone DR, Russell C], Adolf P, Cohen D, Roach T, Stjohn A, Khatri A, Davis K, Mullins J. Goulder PJ, Walker BD, Brander C: Consistent cytotoxic-T. lymphocyte targeting of immunodominant regions in human immunodeficiency virus across multiple ethnicities. J Virol 2004, 78(5):2187-2200.

II. Kiepiela P, Leslie AJ, Honeyborne I, Ramduth D, Thobakgale C, Chetty S, Rathnavalu P, Moore C, Pfafferott KJ. Hilton L, Zimbwa P, Moore S, Allen T, Brander C, Addo MM, Altfeld M, James I, Mallal S, Bunce M, Barber LD, Szinger J, Day C, Klenerman P, Mullins J, Korber $B$, Coovadia HM, Walker BD, Goulder PJ: Dominant influence of HLA-B in mediating the potential co-evolution of HIV and HLA. Nature 2004, 432(70 18):769-775.

12. Novitsky V, Cao H, Rybak N, Gilbert P, McLane MF, Gaolekwe S, Peter T, Thior I, Ndung'u T, Marlink R, Lee TH, Essex M: Magnitude and frequency of cytotoxic T-lymphocyte responses: identification of immunodominant regions of human immunodeficiency virus type I subtype C. J Virol 2002, 76(20): $10155-10168$.

13. Masemola A, Mashishi T, Khoury G, Mohube P, Mokgotho P, Vardas E, Colvin M, Zijenah L, Katzenstein D, Musonda R, Allen S, Kumwenda N, Taha T, Gray G, Mclntyre J, Karim SA, Sheppard HW, Gray CM: Hierarchical targeting of subtype $C$ human immunodeficiency virus type I proteins by CD8+ T cells: correlation with viral load. J Virol 2004, 78(7):3233-3243.

14. Yu XG, Lichterfeld M, Perkins B, Kalife E, Mui S, Chen J, Cheng M, Kang W, Alter G, Brander C, Walker BD, Altfeld M: High degree of inter-clade cross-reactivity of HIV-I-specific $T$ cell responses at the single peptide level. Aids 2005, 19(14): |449-1456.

15. Brander C, Frahm N, Walker BD: The challenges of host and viral diversity in HIV vaccine design. Curr Opin Immunol 2006 , 18(4):430-437.

16. Lu F, Wang N, Wu Z, Sun X, Rehnstrom J, Poundstone K, Yu W, Pisani $E$ : Estimating the number of people at risk for and living with HIV in China in 2005: methods and results. Sex Transm Infect 2006, 82 Suppl 3:iii87-91.

17. Shao Y: AIDS epidemic at age $\mathbf{2 5}$ and control efforts in China. Retrovirology 2006, 3:87.

18. Su L, Graf M, Zhang Y, von Briesen H, Xing H, Kostler J, Melzl H, Wolf $H$, Shao $Y$, Wagner R: Characterization of a virtually full-length human immunodeficiency virus type $I$ genome of a prevalent intersubtype (C/B') recombinant strain in China. J Virol 2000, 74(23): I |367-I| 376

19. Piyasirisilp S, McCutchan FE, Carr JK, Sanders-Buell E, Liu W, Chen J, Wagner R, Wolf H, Shao Y, Lai S, Beyrer C, Yu XF: A recent outbreak of human immunodeficiency virus type $I$ infection in southern China was initiated by two highly homogeneous, geographically separated strains, circulating recombinant form AE and a novel BC recombinant. J Virol 2000, 74(23): I | 286-I | 295.

20. Xing $\mathrm{H}$, Chen Z, Liang $\mathrm{H}$, Feng $Y$, Chen JP, Zhao QB, Zhang $Y Z$, Qin GM, Wei M, Shao YM: The evolution and rapid spread of $B^{\prime} / C$ recombinant HIV-I strains in western China. XIV Int Conf AIDS, TuOrCl/9I 2002 [http://gateway.nlm.nih.gov/MeetingAbstracts/ $102255433 . \mathrm{html}]$. Barcelona, Spain

21. Meng ZF, He X, Ma LY, Peng H, Ma PF, Xu WS, Xing H, Shao YM: Genetic characterization of three CRF07_BC recombinant strain near full-length genome in China. AIDS Res Hum Retroviruses 2007.

22. Rodenburg CM, Li Y, Trask SA, Chen Y, Decker J, Robertson DL, Kalish ML, Shaw GM, Allen S, Hahn BH, Gao F: Near full-length clones and reference sequences for subtype $C$ isolates of HIV type I from three different continents. AIDS Res Hum Retroviruses 200I, I7(2): $16 \mid-168$.

23. Quinones-Mateu ME: Is HIV-I evolving to a less virulent (pathogenic) virus? Aids 2005, 19(15):1689-1690.

24. Ball SC, Abraha A, Collins KR, Marozsan AJ, Baird H, Quinones-Mateu ME, Penn-Nicholson A, Murray M, Richard N, Lobritz M, Zimmerman
PA, Kawamura T, Blauvelt A, Arts E]: Comparing the ex vivo fitness of CCR5-tropic human immunodeficiency virus type I isolates of subtypes B and C. J Virol 2003, 77(2): $1021-1038$.

25. Campbell TB: Are all HIV type I strains created equal? Clin Infect Dis 2006, 42(6):853-854

26. Yu XG, Addo MM, Perkins BA, Wej F, Rathod A, Geer SC, Parta M, Cohen D, Stone DR, Russell CJ, Tanzi G, Mei S, Wurcel AG, Frahm N, Lichterfeld M, Heath L, Mullins JI, Marincola F, Goulder PJ, Brander C, Allen T, Cao Y, Walker BD, Altfeld M: Differences in the expressed HLA class I alleles effect the differential clustering of HIV type I-specific T cell responses in infected Chinese and caucasians. AIDS Res Hum Retroviruses 2004, 20(5):557-564.

27. Wang S, Zhuang Y, Zhai S, Zhao S, Kang W, Li X, Yu XG, Walker BD, Altfeld MA, Sun Y: Association between HIV Type I-specific T cell responses and CD4+ $T$ cell counts or CD4+:CD8+ $T$ cell ratios in HIV Type I subtype B infection in China. AIDS Res Hum Retroviruses 2006, 22(8):780-787.

28. Jiao Y, Xie J, Li T, Han Y, Qiu Z, Zuo L, Wang A: Correlation between gag-specific CD8 $T$-cell responses, viral load, and CD4 count in HIV-I infection is dependent on disease status. J Acquir Immune Defic Syndr 2006, 42(3):263-268.

29. Zhao S, Zhai S, Zhuang Y, Wang S, Huang D, Kang W, Li X, Yu XG, Walker BD, Altfeld MA, Sun Y: Inter-clade cross-reactivity of HIV-I-specific $T$ cell responses in human immunodeficiency virus type I infection in China. Curr HIV Res 2007, 5(2):25 I-259.

30. Lichterfeld M, Yu XG, Cohen D, Addo MM, Malenfant J, Perkins B, Pae E, Johnston MN, Strick D, Allen TM, Rosenberg ES, Korber B, Walker $B D$, Altfeld M: HIV-I Nef is preferentially recognized by CD8 T cells in primary HIV-I infection despite a relatively high degree of genetic diversity. Aids 2004, I 8( I0): I 383-I392.

3I. Yusim K, Kesmir C, Gaschen B, Addo MM, Altfeld M, Brunak S, Chigaev A, Detours V, Korber BT: Clustering patterns of cytotoxic T-lymphocyte epitopes in human immunodeficiency virus type I (HIV-I) proteins reveal imprints of immune evasion on HIV-I global variation. J Virol 2002, 76(I7):8757-8768.

32. Addo MM, Yu XG, Rosenberg ES, Walker BD, Altfeld M: Cytotoxic T-lymphocyte $(C T L)$ responses directed against regulatory and accessory proteins in HIV-I infection. DNA Cell Biol 2002, $2 I(9): 67 \mid-678$.

33. Goulder PJ, Phillips RE, Colbert RA, McAdam S, Ogg G, Nowak MA, Giangrande P, Luzzi G, Morgan B, Edwards A, McMichael AJ, Rowland-Jones S: Late escape from an immunodominant cytotoxic T-lymphocyte response associated with progression to AIDS. Nat Med 1997, 3(2):212-217.

34. Frahm N Kiepiela P, Adams S, Linde $\mathrm{CH}$, Hewitt HS, Sango K, Feeney ME, Addo MM, Lichterfeld M, Lahaie MP, Pae E, Wurcel AG, Roach T, St John MA, Altfeld M, Marincola FM, Moore C, Mallal S, Carrington M, Heckerman D, Allen TM, Mullins Jl, Korber BT, Goulder PJ, Walker BD, Brander C: Control of human immunodeficiency virus replication by cytotoxic $T$ lymphocytes targeting subdominant epitopes. Nat Immunol 2006, 7(2): I73-I78.

35. Bhattacharya T, Daniels M, Heckerman D, Foley B, Frahm N, Kadie C, Carlson J, Yusim K, McMahon B, Gaschen B, Mallal S, Mullins JI, Nickle DC, Herbeck J, Rousseau C, Learn GH, Miura T, Brander C, Walker $B$, Korber B: Founder effects in the assessment of HIV polymorphisms and HLA allele associations. Science 2007 , 3I5(58 I8): I583-I586

36. Coplan PM, Gupta SB, Dubey SA, Pitisuttithum P, Nikas A, Mbewe B, Vardas E, Schechter M, Kallas EG, Freed DC, Fu TM, Mast CT, Puthavathana P, Kublin J, Brown Collins K, Chisi J, Pendame R, Thaler SJ, Gray G, Mclntyre J, Straus WL, Condra JH, Mehrotra DV, Guess HA, Emini EA, Shiver JW: Cross-reactivity of anti-HIV-I T cell immune responses among the major HIV-I clades in HIV-Ipositive individuals from 4 continents. I Infect Dis 2005, | 9 I(9): | $427-1434$.

37. Francois-Bongarcon $\vee$, Feng $Y$, Lee $S K$, Chen $G$, Shankar $P$, Liu $Y$, Tao $X$, Shao $Y$, Lieberman J: Cross-clade CD8 T-cell responses to HIV(IIIB) and Chinese B' and C/B' viruses in North American and Chinese HIV-seropositive donors. I Acquir Immune Defic Syndr 2004, 37(4): I435-I444.

38. Altfeld M, Addo MM, Shankarappa R, Lee PK, Allen TM, Yu XG, Rathod A, Harlow J, O'Sullivan K, Johnston MN, Goulder PJ, Mullins Il, Rosenberg ES, Brander C, Korber B, Walker BD: Enhanced detection of human immunodeficiency virus type I-specific T-cell responses to highly variable regions by using peptides 
based on autologous virus sequences. I Virol 2003, 77(13):7330-7340.

39. Ogg GS, Jin X, Bonhoeffer S, Dunbar PR, Nowak MA, Monard S, Segal JP, Cao Y, Rowland-Jones SL, Cerundolo V, Hurley A, Markowitz M, Ho DD, Nixon DF, McMichael AJ: Quantitation of HIV-I-specific cytotoxic T lymphocytes and plasma load of viral RNA. Science 1998, 279(5359):2103-2106.

40. Edwards BH, Bansal A, Sabbaj S, Bakari J, Mulligan MJ, Goepfert PA: Magnitude of functional CD8+ T-cell responses to the gag protein of human immunodeficiency virus type I correlates inversely with viral load in plasma. J Virol 2002, 76(5):2298-2305.

41. Sheth PM, Danesh A, Shahabi K, Rebbapragada A, Kovacs C, Dimayuga R, Halpenny R, Macdonald KS, Mazzulli T, Kelvin D, Ostrowski M, Kaul R: HIV-specific CD8+ lymphocytes in semen are not associated with reduced HIV shedding. J Immunol 2005, I 75(7):4789-4796.

42. Gamberg J, Barrett L, Bowmer MI, Howley C, Grant M: Factors related to loss of HIV-specific cytotoxic T lymphocyte activity. Aids 2004, 18(4):597-604.

43. Karlsson AC, Iversen AK, Chapman JM, de Oliviera T, Spotts G McMichael AJ, Davenport MP, Hecht FM, Nixon DF: Sequential Broadening of CTL Responses in Early HIV-I Infection Is Associated with Viral Escape. PLOS ONE 2007, 2:e225.

44. Martinez-Picado J, Prado JG, Fry EE, Pfafferott K, Leslie A, Chetty S, Thobakgale C, Honeyborne I, Crawford H, Matthews P, Pillay T, Rousseau C, Mullins JI, Brander C, Walker BD, Stuart DI, Kiepiela P, Goulder P: Fitness cost of escape mutations in p24 Gag in association with control of human immunodeficiency virus type I. J Virol 2006, 80(7):3617-3623.

45. Klase Z, Donio MJ, Blauvelt A, Marx PA, Jeang KT, Smith SM: A peptide-loaded dendritic cell based cytotoxic T-lymphocyte (CTL) vaccination strategy using peptides that span SIV Tat, Rev, and Env overlapping reading frames. Retrovirology 2006, 3:I.

46. Dalod M, Dupuis M, Deschemin JC, Goujard C, Deveau C, Meyer L, Ngo N, Rouzioux C, Guillet JG, Delfraissy JF, Sinet M, Venet A: Weak anti-HIV CD8(+) T-cell effector activity in HIV primary infection. J Clin Invest 1999, 104(10): 1431-1439.

47. Kalams SA, Walker BD: The critical need for CD4 help in maintaining effective cytotoxic $\mathrm{T}$ lymphocyte responses. J Exp Med 1998, 188( ( 2):2199-2204.

48. Lichterfeld M, Yu XG, Mui SK, Williams KL, Trocha A, Brockman MA, Allgaier RL, Waring MT, Koibuchi T, Johnston MN, Cohen D, Allen TM, Rosenberg ES, Walker BD, Altfeld M: Selective depletion of high-avidity human immunodeficiency virus type I (HIV-I)specific CD8+ T cells after early HIV-I infection. J Virol 2007, $8 I(8): 4|99-42| 4$.

49. Day CL, Kiepiela P, Leslie AJ, van der Stok M, Nair K, Ismail N, Honeyborne I, Crawford H, Coovadia HM, Goulder PJ, Walker BD Klenerman P: Proliferative capacity of epitope-specific CD8 Tcell responses is inversely related to viral load in chronic human immunodeficiency virus type I infection. J Virol 2007 $81(1): 434-438$.

50. The Los Alamos HIV Database [http://www.hiv.lanl.gov]

5I. Yu XG, Shang H, Addo MM, Eldridge RL, Phillips MN, Feeney ME, Strick D, Brander C, Goulder PJ, Rosenberg ES, Walker BD, Altfeld M: Important contribution of pI5 Gag-specific responses to the total Gag-specific CTL responses. Aids 2002, 16(3):321-328.
Publish with Biomed Central and every scientist can read your work free of charge

"BioMed Central will be the most significant development for disseminating the results of biomedical research in our lifetime. "

Sir Paul Nurse, Cancer Research UK

Your research papers will be:

- available free of charge to the entire biomedical community

- peer reviewed and published immediately upon acceptance

- cited in PubMed and archived on PubMed Central

- yours - you keep the copyright

Submit your manuscript here:

http://www.biomedcentral.com/info/publishing_adv.asp
BiolMedcentral 